\title{
End-of-life decision-making is difficult (problems with the Consent and Capacity Board)
}

\author{
Robert Sibbald, MSc iD
}

Received: 29 March 2018/Revised: 5 June 2018/Accepted: 6 June 2018/Published online: 6 July 2018

(c) Canadian Anesthesiologists' Society 2018

\section{To the Editor,}

Family members face difficult decisions when an incapable loved one is nearing death or in a state of permanent incapacity being supported by technology. It is a tragic consequence of modern medicine and current consent legislation that family members are often put in the position of weighing conflicting plans for death-one characterized by minimizing potential harms or indignities and one characterized by chronic life support and ongoing resuscitation.

Physicians can face difficult decisions when families in such circumstance do not recognize that death is at the end of either choice. These families often opt for a "fight"against evidence, odds, and the advice of experienced clinicians-seemingly against death itself. While statements and position papers offer nuanced advice for clinicians, ${ }^{1,2}$ there are limited realistic strategies in the face of intractable conflict (i.e., conflict that endures beyond mediation, compromise, ethics consults, etc.). Physicians can make unilateral decisions to limit/withdraw treatments, often triggering legal action initiated by families, or they can acquiesce to family demands-tough decisions. In Ontario, physicians have another option through the Consent and Capacity Board (CCB), whose mission it is to provide "fair and accessible adjudication of consent and capacity issues". A

R. Sibbald, MSc ( $₫)$

Department of Family Medicine, Schulich School of Medicine,

Western University, London, ON, Canada

e-mail: Robert.Sibbald@1hsc.on.ca

R. Sibbald, MSc

London Health Sciences Centre, London, ON, Canada
In the first seven years since the first such application was made to the CCB in 2003, each of the 16 cases taken to the $\mathrm{CCB}$ to resolve end-of-life conflict endorsed either limits or withdrawal of treatment to allow patients to die (typically in a matter of weeks). Nevertheless, since 2010, 18 of $39(46 \%)$ cases were dismissed in a manner that appeared as if the CCB's intention was to avoid difficult decisions. ${ }^{\mathrm{B}}$

Consider the recent case of a 24-yr-old male who suffered irreversible brain damage following a sudden cardiac arrest with prolonged anoxia. When his physicians sought to discontinue ventilation and opt instead for palliation, the CCB dismissed the application because the consequences of a treatment decision (i.e., a requirement of consent) "had not proven to have been provided in a fulsome form to the substitute decision-maker prior to requesting a decision", even though they were "well addressed at the hearing". ${ }^{\circ}$

In a case of an infant with severe neurologic injury, the $\mathrm{CCB}$ expressed that the application was "premature",

\footnotetext{
$\overline{\mathrm{A}}$ Consent and Capacity Board. Available from URL: www.ccboard. on.ca/scripts/english/aboutus/index.asp (accessed June 2018).

B Healthcare Consent Quality Collaborative. End of Life Cases. Available from URL: www.consentqi.ca (accessed June 2018).

C Consent and Capacity Board. 17-2473-01; 17-2473-02. In the matter of The Health Care Consent Act. S.O. 1996 c.2, as amended. And in the matter of NS-a patient at William Osler Health SystemBrampton Civic Hospital, Brampton, Ontario. Available from URL: www.canlii.org/en/on/onccb/doc/2017/2017canlii86486/2017canlii 86486.pdf (accessed June 2018).

D Consent and Capacity Board. 14-0195-1; 14-0195-02. In the matter of Health Care Consent Act. S.O. 1996, chapter 2, schedule A, as amended. And in the matter of $\mathrm{CN}$ also known as $\mathrm{CK}-\mathrm{A}$ patient at London Health Sciences Centre-Victoria Hospital, London, Ontario. Available from URL: www.canlii.org/en/on/onccb/doc/2014/ 2014canlii53714/2014canlii53714.pdf (accessed June 2018).
} 
implication being that regardless of the medical evidence of an unchanging condition, somehow additional time was necessary to allow decision-makers to accept an eventual death that we argue was without regard to the patient's best interest.

In the case of a 58 yr old who suffered multiple strokes that left her in a near-vegetative state, the CCB said, "Without specific direction from the patient, the daughter resorts to her religious beliefs and those of her mother insisting that life be prolonged, no matter what the suffering." $\mathrm{E}$ This statement is contravened by the law that requires consideration of the patient's values, not those of the substitute decision-maker; it additionally requires consideration of the medical evidence (e.g., is the treatment likely to benefit the patient's condition?). ${ }^{3}$

These are only a few of the examples of troubling decisions taken by the CCB. We have come to a point where the legal system seems to favour treatment at the end of life irrespective of outcome, medical evidence, or suffering. The result of these cases is that many physicians no longer consider the CCB a useful resource. That said, the alternatives are not appealing either. Unless physicians want to see their critical care units filled with patients who are destined to remain minimally conscious and on maximal life supports for years before they die, they have another difficult choice to make. Physicians in Ontario should not only be willing to apply to the CCB in the first place; they must be willing to appeal bad decisions and prolong the legal process for the benefit of current and future patients. Difficult decisions.

Conflict of interest The author has no competing interests to declare.

Editorial Responsibility This submission was handled by Dr. Hilary P. Grocott, Editor-in-Chief, Canadian Journal of Anesthesia.

\section{References}

1. Canadian Critical Care Society Ethics Committee; Bandrauk N, Downar J, Paunovic B.. Withholding and withdrawing lifesustaining treatment: The Canadian Critical Care Society Position Paper. Can J Anesth 2018; 65: 105-22.

2. Bosslet GT, Pope TM, Rubenfeld GD, et al. An official ATS/ AACN/ACCP/ESICM/SCCM policy statement: Responding to requests for potentially inappropriate treatments in intensive care units. Am J Resp Crit Care Med 2015; 191: 1318-30.

3. Health Care Consent Act, 1996, S.O. 1996, c. 2, s. 21. Sched. A. Available from URL: https://www.ontario.ca/laws/statute/96h02 (accessed June 2018).

\footnotetext{
$\overline{\mathrm{E}}$ Consent and Capacity Board. File No. LO-10-3745; File No. LO10-3746. In the matter of Health Care Consent Act-S.O. 1996, c.2 as amended. And in the matter of " $\mathrm{S} \mathrm{S}$ ", a patient of Grand-River Hospital-Kitchener-Waterloo Health Centre, Kitchener, Ontario. Available from URL: www.canlii.org/en/on/onccb/doc/2011/ 2011canlii5000/2011canlii5000.pdf (accessed June 2018).
} 